Short Communication

\title{
Redox Mediators Assisted-degradation of Direct Yellow 4
}

\author{
Shazia Nouren ${ }^{1}$, Haq Nawaz Bhatti ${ }^{2}$, Munawar Iqbal ${ }^{3 *}$, Ismat Bibi ${ }^{4}$, Nosheen Nazar ${ }^{4}$, \\ Dure Najaf Iqbal $^{3}$, Qudsia Kanwal ${ }^{3}$, Abida Kausar ${ }^{5}$, Fida Hussain ${ }^{6}$
}

\author{
${ }^{1}$ Department of Chemistry, Govt. College Women University, Sialkot, Pakistan \\ ${ }^{2}$ Department of Chemistry, University of Agriculture, Faisalabad, Pakistan \\ ${ }^{3}$ Department of Chemistry, University of Lahore, Lahore, Pakistan \\ ${ }^{4}$ Department of Chemistry, Islamia University Bahawalpur, Pakistan \\ ${ }^{5}$ Department of Chemistry, Government College Women University, Faisalabad, Pakistan \\ ${ }^{6}$ Department of Botany, Qurtuba University of Science and Information, \\ Technology \& Islamia College, Peshawar, Pakistan
}

Received: 13 October 2016

Accepted: 18 January 2017

\begin{abstract}
Direct yellow 4 degradation was investigated in the presence of various mediators ( $p$-coumaric acid, 1 , hydroxybenzotriazole (HOBT), syringaldehyde, vanillin, syringic acid, veratryl alcohol, and pyrocatechol) at pre-optimized conditions of process variables, i.e., $\mathrm{pH}$ 5.0, temperature $50^{\circ} \mathrm{C}$, enzyme dose $24 \mathrm{U} / \mathrm{mL}$, and $0.25 \mathrm{mM} \mathrm{H}_{2} \mathrm{O}_{2}$ concentration. Citrus limon peroxidase (CL-POD) was used for degradation of DY4 dye. In the absence of mediators, the DY4 degradation was $60 \%$, whereas mediators enhanced the POD biodegradation efficiency up to $87 \%$. Among mediators investigated, syringaldehyde showed promising efficiency. We investigated yringaldehyde concentrations in the range of $0.0125-0.5 \mathrm{mM}$, and $0.025 \mathrm{mM}$ was optimum for maximum dye degradation, which revealed that mediators could be used to enhance the biodegradation of dyes.
\end{abstract}

Keywords: Citrus limon peroxidase, decolorization, direct yellow 4, redox mediators

\section{Introduction}

Dyes are widely used in the food, cosmetics, leather, textile, paper, and plastic industries, and subsequently discharged into the environment. Other than toxicity of dyes [1-3], they also alter water colour, cause eutrophication, and deplete oxygen, which ultimately

*e-mail: bosalvee@yahoo.com disturbs aquatic life [1, 4-6]. So far, dye remediation is compulsory for avoiding environmental pollution issues [7-10]. Among wastewater treatment methods, biodegradation has received considerable attention due to its eco-friendly, economical, and efficient nature. In the biodegradation process, different enzymes are utilized, and among enzymes, POD are reported to be efficient for the degradation of diverse types of pollutants $[6,11-$ 12], i.e., POD from hoseradish [13], soybean [14], and Cucubita pepo [15] are reported to be highly efficient for the degradation of dyes. Pakistan is a citrus-producing 
country and the huge amount of waste peels that are generated is an efficient POD source [16-17].

The present study was conducted to apprise the CLPOD-mediated degradation of DY4 dye. The effect of various mediators was studied in detail on DY4 degradation using optimum conditions of $\mathrm{pH}$, temperature, incubation time, enzyme dose, $\mathrm{H}_{2} \mathrm{O}_{2}$ amount, and dye concentration.

\section{Materials and Methods}

\section{Chemicals and Reagents}

The chemicals and reagents used were of analytical grade, i.e., dipotassium phosphate (99\%), potassium dihydrogen phosphate (99\%), ammonium sulphate (99\%), sodium carbonate $(99 \%)$, and hydrogen peroxide $(30 \%)-$ all of which were purchased from Sigma-Aldrich Chemical Co. USA. DY4 was obtained from local textile industries in Faisalabad, Pakistan. Ultra-pure water (18.2 $\Omega . \mathrm{cm})$ from Milli-Q system (Millipore) was used throughout the study for solution preparation.
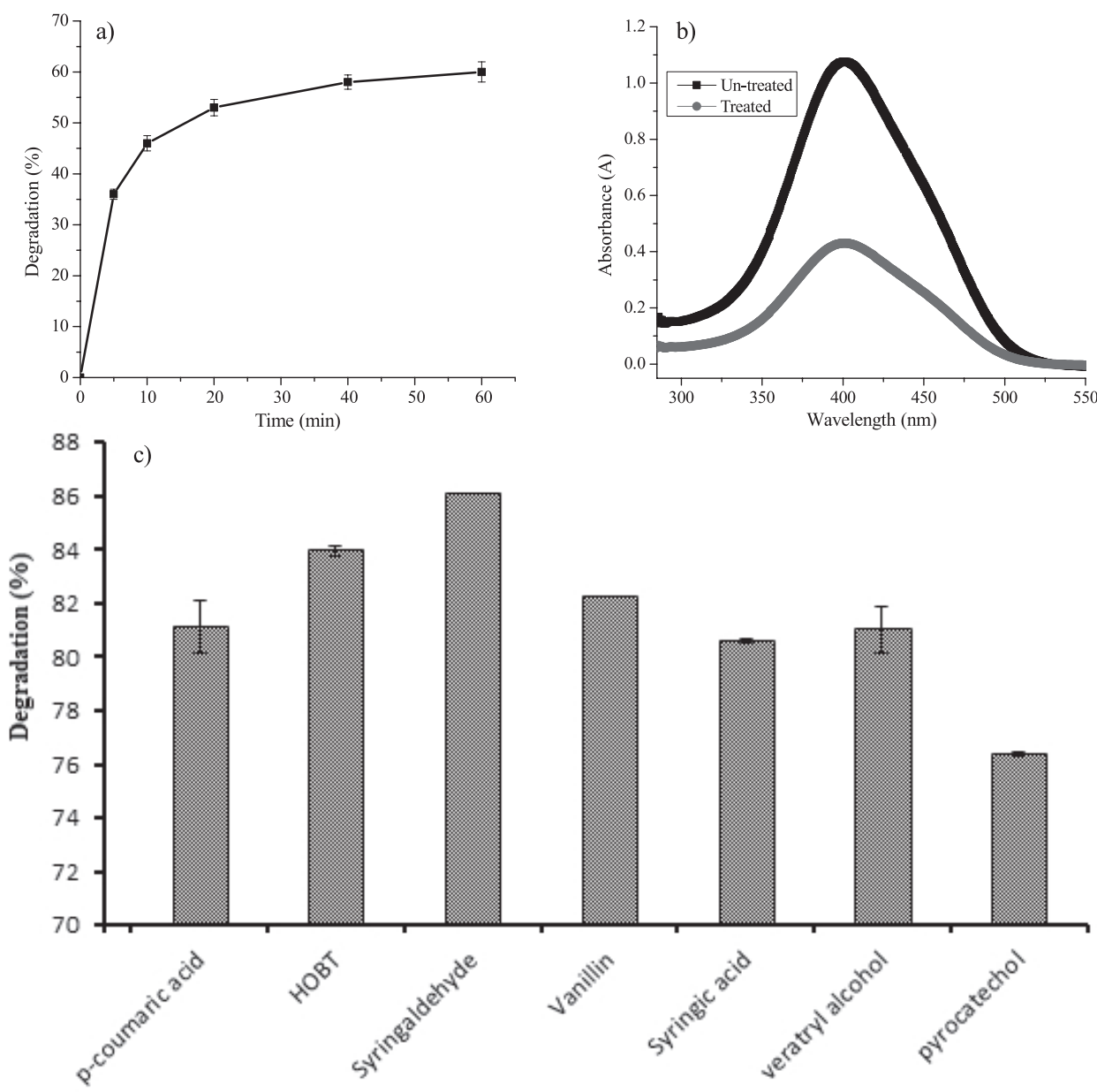

Mediators

Fig. 1. a) Bio-degradation of direct yellow 4 (DY4) dye without mediator ( $\mathrm{pH} 5.0,50^{\circ} \mathrm{C}$, enzyme dose $24 \mathrm{U} / \mathrm{mL}, \mathrm{H}_{2} \mathrm{O}_{2}$ concentration $0.25 \mathrm{mM}$, incubation time $30 \mathrm{~min}$, and DY4 concentration $18.75 \mathrm{mg} / \mathrm{L}$ ), b) UV-Vis spectrum of DY4 dye in the absence of mediator, and c) effect of various redox mediators on Citrus limon peroxidase (CL-POD) efficiency on DY4 degradation.
To study the effect of mediators ( $p$-coumaric acid, 1 , hydroxybenzotriazole (HOBT), syringaldehyde, vanillin, syringic acid, veratryl alcohol, and pyrocatechol) on dye degradation, $\mathrm{pH} 5.0$, temperature $50^{\circ} \mathrm{C}$, enzyme dose $24 \mathrm{U} / \mathrm{mL}, \mathrm{H}_{2} \mathrm{O}_{2}$ concentration $0.25 \mathrm{mM}$, and DY4 concentration $18.75 \mathrm{mg} / \mathrm{L}$ was kept constant. The DY4 solution was mixed with respective amounts of mediators and placed in a shaker (Model PA 9/250 U). After a stipulated time period, samples were drawn and kept in centrifuged (10,000 rpm for $5 \mathrm{~min}$ ) and absorbance was recorded along with control (untreated dye sample) at $\lambda_{\text {max }}$ 402. The percentage dye degradation was calculated using the relationship shown in Eq. 1:

... where $\mathrm{A}_{\mathrm{i}}$ and $\mathrm{A}_{\mathrm{f}}$ are the absorbance values of un-treated and treated dyes.

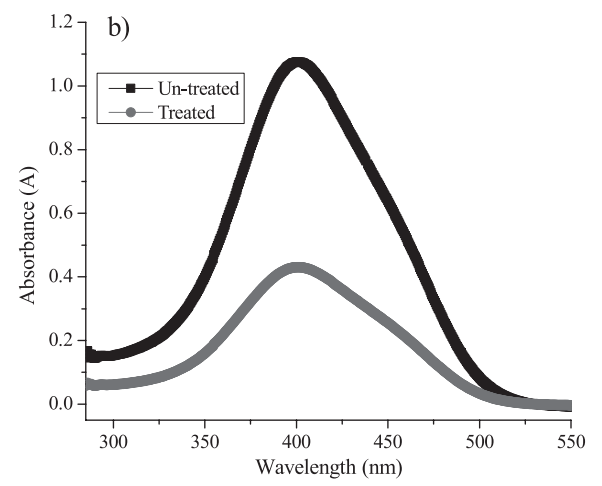

. water bath for $10 \mathrm{~min}$ to stop the reaction, which was then

$$
\text { Decolorization }(\%)=\left\lceil\frac{A_{i}-A_{f}}{A_{i}}\right\rceil \times 100
$$




\section{Results and Discussion}

CL-POD-mediated decolourization of DY4 in the presence of various mediators was investigated. The effect of mediators was studied by degradating DY4 using pre-optimized conditions of process variables, i.e., $\mathrm{pH}$ 5.0, $50^{\circ} \mathrm{C}$, enzyme dose $24 \mathrm{U} / \mathrm{mL}, \mathrm{H}_{2} \mathrm{O}_{2}$ concentration $0.25 \mathrm{mM}$, and DY4 concentration $18.75 \mathrm{mg} / \mathrm{L}$. Without a mediator, DY4 degradation was $60 \%$ (Figs 1a-b). However, mediators (i.e., $p$-coumaric acid, 1, HOBT, syringaldehyde, vanillin, syringic acid, veratryl alcohol and pyrocatechol) enhanced DY4 degradation significantly (Fig. 1c). p-coumaric acid, HOBT, syringaldehyde, vanillin, syringic acid, veratryl alcohol, and pyrocatechol showed the dye degradation up to $81.1 \%, 84.2 \%$, $86.3 \%, 82.05 \%, 80.3 \%, 81.5 \%$, and $77.3 \%$, respectively. Degradation response of dye revealed that $p$-coumaric acid, HOBT, syringaldehyde, vanillin, syringic acid, veratryl alcohol, and pyrocatechol enhanced the DY4 degradation in the range of 17 to $25 \%$ versus control. It is well known that under typical conditions, the enzymes interact with substrate and the catalytic site of the enzyme abstracts electrons from the substrate and transformed it into a byproduct. The mediators oxidized by the enzyme oxidize the dye molecule, which results in the substrate being converted into oxidized product. Therefore, mediators may offer more possibilities, i.e., either indirectly oxidizing the dye molecule/enabling the enzyme to attack substrate, thereby leading to enhanced oxidation of the target compound [18-19]. Among mediators under investigation, syringaldehyde efficiency was promising in enhancing dye degradation. In subsequent experiments, various concentrations of syringaldehyde were studied and results thus obtained are shown in Fig. 2a). The different concentrations of syringaldehyde showed a variable effect on dye degradation, which indicates that syringaldehyde is very effective in enhancing dye biodegradation. The concentration of $0.025 \mathrm{mM}$ showed the highest dye degradation ability. The variable effect of mediators on degradation can be correlated with different natural mediators and their electron-donating ability. Degradation is governed by redox potential of the mediator and oxidation mechanism of the substrate. So far, different mediators showed variable behaviour for dye degradation. Figs 2(b-c) depict the effect of time of incubation on degradation of DY4 in the presence of $0.025 \mathrm{mM}$ syringaldehyde $(0.025 \mathrm{mM})$, which showed degradation of $89 \%$ within a very short time interval. These findings are in line with maximum dye degradation being achieved using suitable mediators [20].

Previous studies also revealed that redox mediators enhanced the dye degradation efficiently [21-22].
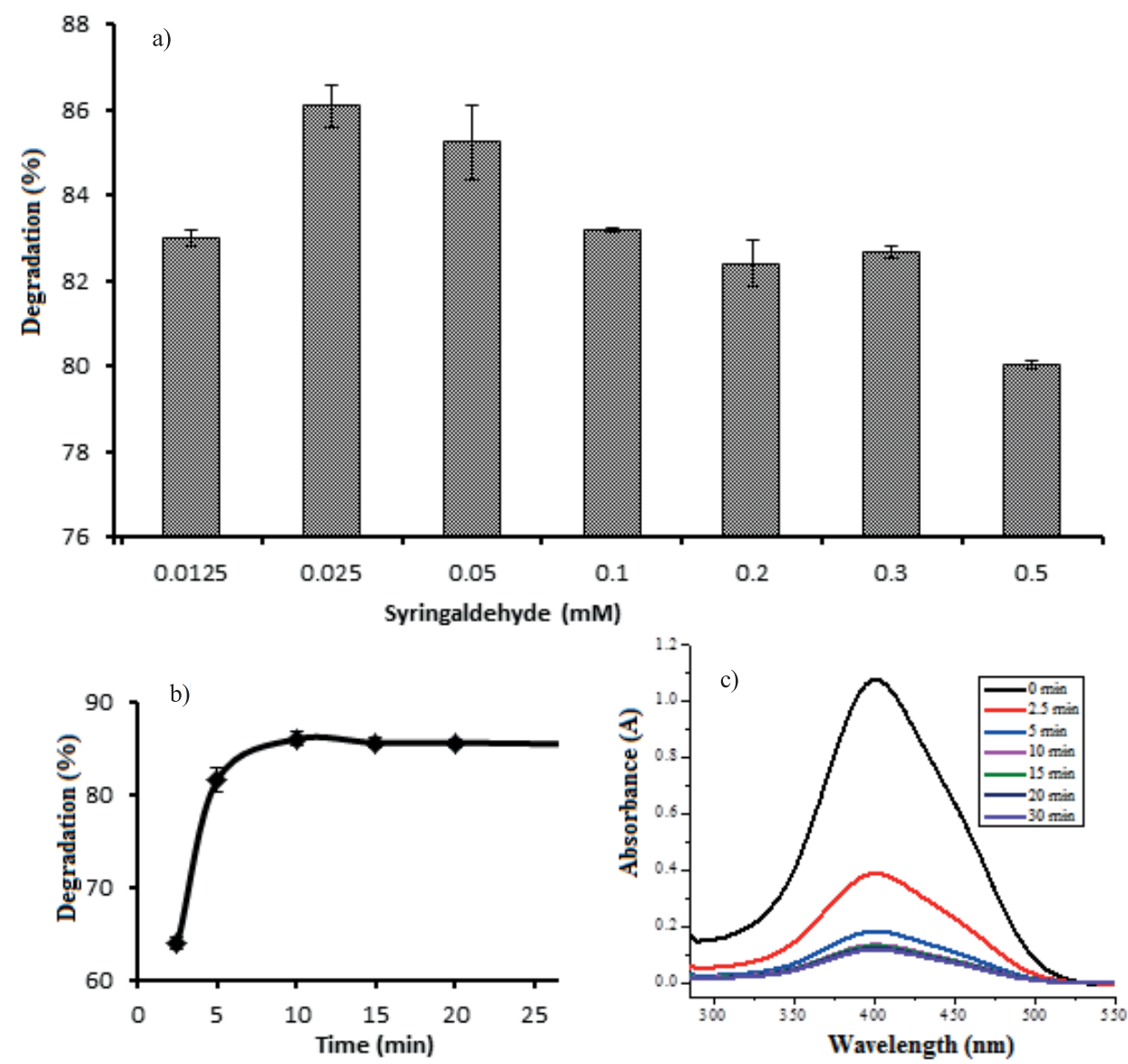

Fig. 2. a) Effect of different concentrations of syringaldehye (mediator) on DY4 bio-degradation by CL-POD, b) effect of incubation time on degradation of DY 4 in the presence of syringaldehyde $(0.025 \mathrm{mM})$, and c) UV-Vis spectrum of DY4 in the presence of syringaldehyde. 
Hydroxybenzotriazole proved to be an efficient mediator for plant-based POD-mediated biodegradation. Decolourization of effluents by $T$. foenum-graecum seeds [23] and M. charantia POD [24] and mixtures of acidic dyes treated by turnip POD also showed promising efficiency [25]. In the present investigation, syringaldehyde (0.0125-0.5 mM) was studied and maximum degradation of DY4 was achieved at $0.025 \mathrm{mM}$ concentration level, and beyond this concentration the degradation rate decreased. The same trend was observed previously for violuric acid as a redox mediator for turnip POD effect on degradation of dispersed dyes. The dye degradation enhancing effects of mediators have been correlated with dual role mediators. However, lower mediator concentration was found to be efficient and at higher concentration low efficiency was reported, which was due to the competitive inhibition of active sites, thus inhibiting enzyme activity at higher concentrations [26]. Therefore, optimizing the mediator is important for effective biodegradation of dyes. So far, based on results, the mediators proved to be efficient in enhancing POD dye degradation capability. Biodegradation is an eco-friendly method [2742] that could be used to enhance bio-degradation of dye and textile wastewater to avoid environmental pollution [43-68].

\section{Conclusions}

DY4 degradation was investigated in the presence of various redox mediators at pre-optimized conditions of $\mathrm{pH}$, temperature, enzyme dose, and $\mathrm{H}_{2} \mathrm{O}_{2}$ concentration. In the presence of redox mediators, up to $89 \%$ degradation was achieved (including 60\% without mediators). $p$-coumaric acid, HOBT, syringaldehyde, vanillin, syringic acid, veratryl alcohol, and pyrocatechol efficiency were lower than for syringaldehyde and significantly higher than control. The low concentration of mediators was more effective as compared to higher concentrations. In view of the promising efficiency of mediators, these could possibly be used to enhance the bio-degradation efficiency of enzymes.

\section{References}

1. IQBAL M. Vicia faba bioassay for environmental toxicity monitoring: a review. Chemosphere. 144, 785, 2016.

2. IQBAL M., ABBAS M., ARSHAD M., HUSSAIN T., KHAN A.U., MASOOD N., Gamma radiation treatment for reducing cytotoxicity and mutagenicity in industrial wastewater. Pol. J. Environ. Stud. 24, 2745, 2015.

3. IQBAL M., NISAR J. Cytotoxicity and mutagenicity evaluation of gamma radiation and hydrogen peroxide treated textile effluents using bioassays. J. Environ. Chem. Eng. 3, 1912, 2015.

4. SAEED M., ADEEL S., ILYAS M., SHAHZAD M.A., USMAN M., HAQ E-U. Oxidative degradation of Methyl Orange catalyzed by lab prepared nickel hydroxide in aqueous medium. Desalin. Water Treat. 57, 12804, 2016.
5. BILAL M., ASGHER M., IQBAL M., HU H., ZHANG X. Chitosan beads immobilized manganese peroxidase catalytic potential for detoxification and decolorization of textile effluent. Int. J. Biol. Macromol. 89, 181, 2016.

6. BILAL M., IQBAL M., HU H., ZHANG X. Mutagenicity and cytotoxicity assessment of biodegraded textile effluent by $\mathrm{Ca}$-alginate encapsulated manganese peroxidase. Biochem. Eng. J. 109, 153, 2016.

7. SASMAZ M., AKGUL B., YILDIRIM D., SASMAZ A. Bioaccumulation of thallium by the wild plants grown in soils of mining area. Int. J. Phytoremed. 18, 1164, 2016.

8. SASMAZ M., AKGÜL B., YILDIRIM D., SASMAZ A. Mercury uptake and phytotoxicity in terrestrial plants grown naturally in the Gumuskoy (Kutahya) mining area, Turkey. Int. J. Phytoremed. 18, 69, 2016.

9. SASMAZ M., OBEK E., SASMAZ A. Bioaccumulation of Uranium and Thorium by Lemna minor and Lemna gibba in Pb-Zn-Ag Tailing Water. Bull. Environ. Contam. Toxicol. 97, 832, 2016.

10. UKPAKA C., WAMI E., AMADI S. Effect of pollution on metal corrosion: a case study of carbon steel metal in acidic media. Curr. Sci. Perspect. 1, 107, 2015.

11. BILAL M., ASGHER M. Sandal reactive dyes decolorization and cytotoxicity reduction using manganese peroxidase immobilized onto polyvinyl alcohol-alginate beads. Chem. Central J. 9, 1, 2015.

12. BILAL M., ASGHER M. Dye decolorization and detoxification potential of $\mathrm{Ca}$-alginate beads immobilized manganese peroxidase. BMC Biotechnol. 15, 1, 2015.

13. ONDER S., CELEBI M., ALTIKATOGLU M., HATIPOGLU A., KUZU H. Decolorization of naphthol blue black using the horseradish peroxidase. Appl. Biochem. Biotechnol. 163, 433, 2011

14. ALI L., ALGAITHI R., HABIB H.M., SOUKA U., RAUF M.A., ASHRAF S.S. Soybean peroxidase-mediated degradation of an azo dye - a detailed mechanistic study. BMC Biochem. 14, 1, 2013.

15. BOUCHERIT N., ABOUSEOUD M., ADOUR L. Degradation of direct azo dye by Cucurbita pepo free and immobilized peroxidase. J. Environ. Sci. 25, 1235, 2013.

16. NOUREN S., BHATTI H., BHATTI I., ASGHER M. Kinetic and thermal characterization of peroxidase from peels of Citrus reticulata var. Kinnow. J. Animal Plant Sci. 23, 430, 2013.

17. MOHAMED S.A., EL-BADRY M.O., DREES E.A., FAHMY A.S. Properties of a cationic peroxidase from Citrus jambhiri cv. Adalia. Appl. Biochem. Biotechnol. 150, 127, 2008.

18. SOARES G.M., DE AMORIM M.P., COSTA-FERREIRA $M$. Use of laccase together with redox mediators to decolourize Remazol Brilliant Blue R. J. Biotechnol. 89, 123, 2001.

19. HUSAIN M., HUSAIN Q. Applications of redox mediators in the treatment of organic pollutants by using oxidoreductive enzymes: a review. Crit. Rev. Environ. Sci. Technol. 38, 1, 2007.

20. GHODAKE G.S., KALME S.D., JADHAV J.P., GOVINDWAR SP. Purification and partial characterization of lignin peroxidase from Acinetobacter calcoaceticus NCIM 2890 and its application in decolorization of textile dyes. Appl. Biochem. Biotechnol. 152, 6, 2009.

21. BAIOCCO P., BARRECA A.M., FABBRINI M., GALLI C., GENTILI P. Promoting laccase activity towards nonphenolic substrates: a mechanistic investigation with some laccase-mediator systems. Org. Biomol. Chem. 1, 191, 2003. 
22. ALBUQUERQUE M., LOPES A., SERRALHEIRO M., NOVAIS J., PINHEIRO H. Biological sulphate reduction and redox mediator effects on azo dye decolourisation in anaerobic-aerobic sequencing batch reactors. Enzyme Microb. Technol. 36, 790, 2005.

23. HUSAIN Q., KARIM Z., BANDAY Z.Z. Decolorization of textile effluent by soluble fenugreek (Trigonella foenumgraecum L.) seeds peroxidase. Water Air Soil Poll. 212, 319, 2010.

24. MATTO M, HUSAIN Q. Decolorization of textile effluent by bitter gourd peroxidase immobilized on concanavalin A layered calcium alginate-starch beads. J. Hazard. Mater. 164, 1540, 2009.

25. KULSHRESTHA Y., HUSAIN Q. Decolorization and degradation of acid dyes mediated by salt fractionated turnip (Brassica rapa) peroxidases. Toxicol. Environ. Chem. 89, 255, 2007.

26. MATTO M, HUSAIN Q. Decolorization of direct dyes by salt fractionated turnip proteins enhanced in the presence of hydrogen peroxide and redox mediators. Chemosphere. 69, 338, 2007.

27. EHSAN S., SARFRAZ S., KHAN B., HASSAN S.M., IQBAL M. A rapid solid supported synthesis of 4-amino-5(pyridin-4-YL)-4H-1, 2, 4-triazol-3-thiol and its derivatives. Chem. Int. 2, 262, 2016.

28. ELVIA R., CAHYANA A.H., WIBOWO W. Catalytic acetylation of $(+)$-cedrol with heterogeneous catalyst $\mathrm{H}_{2} \mathrm{SO}_{4} / \mathrm{SiO}_{2}$ under solvent free conditions. Chem. Int. 1, 196, 2015.

29. GANGADHARA R., PRASAD N. Studies on optimization of transesterification of certain oils to produce biodiesel. Chem. Int. 2, 59, 2016.

30. GUL S, KHANUM K, MUJTABA N. New validated method for analysis of salymarin in polyherbal formulation (aqueous extract, oral liquid and solid dosage form). Chem. Int. 1, 103, 2015.

31. KHERA R.A., IQBAL M. Nanoscale bioactive glasses and their composites with biocompatible polymers. Chem. Int. 1, 17, 2015.

32. KOUSAR N., ALI S., SHAHZADI S., RUKH L., RAMZAN S., SHAHID M. Synthesis, characterization and antimicrobial activities of organotin (IV) complexes with ethylthioglycolate. Chem. Int. 1, 92, 2015.

33. OGONI H., UKPAKA C., IZIONWORU V. Evaluation of substrate uptake by microbial film in a gel-like medium. Chem. Int. 2, 176, 2016.

34. OJEZELE M.O., ERHIRHIE E.O., AROJOJOYE O.A. Effects of Viscum album (mistletoe) from three host plants (cocoa, kola and coffee) on semen quality of wistar albino rats. Chem. Int. 2, 109b, 2016.

35. RANE A., ABITHA V., SABNIS A., KATHALEWAR M., JAMDAR V., PATIL S. A greener and sustainable approach for converting polyurethane foam rejects into superior polyurethane coatings. Chem. Int. 1, 184, 2015.

36. REMYA V., PATIL D., ABITHA V., RANE A.V., MISHRA R.K. Biobased materials for polyurethane dispersions. Chem. Int. 2, 158, 2016.

37. SHARMA S.K. Eco-friendly and fast bromination of industrially-important aromatic compounds in water using recyclable $\mathrm{AlBr}_{3}-\mathrm{Br}_{2}$ system. Chem. Int. 1, 60, 2015.

38. SHARMA S.K, AGARWAL D. A Direct and simplistic Bromination of commercially important organic compounds in aqueous media by eco-friendly $\mathrm{AlBr} 3-\mathrm{Br} 2$ reagent system. Chem. Int. 1, 106, 2015.

39. SHARMA S.K., AGARWAL D. Synthesis of cetylpyridiniumtribromide (CetPyTB) reagent by noble synthetic route and bromination of organic compounds using CetPyTB. Chem. Int. 1, 64, 2015.

40. SOLANKEE A., TAILOR R. An efficient synthesis of some new chalcone, acetyl pyrazoline and amino pyrimidine bearing 1,3,5-triazine nucleus as potential antimicrobial and antitubercular agent. Chem. Int. 2, 189, 2016.

41. SRIVASTAVA S., SRIVASTAVA P., GUPTA V., JAISWAL A. Homogeneous catalytic oxidation of some polyhydric alcohols by iridium trichloride. Chem. Int. 3, 19, 2017.

42. ZHAO Y., WANG D., LI X., LIU Y. Determination of rutin, chlorogenic acid and quercetin in solidaginis by large volume sample stacking with polarity switching and acid barrage stacking. Chem. Int. 2, 121, 2016.

43. BABARINDE A., OGUNDIPE K., SANGOSANYA K.T., AKINTOLA B.D., ELIZABETH HASSAN A-O. Comparative study on the biosorption of $\mathrm{Pb}$ (II), $\mathrm{Cd}$ (II) and $\mathrm{Zn}(\mathrm{II})$ using Lemon grass (Cymbopogon citratus): kinetics, isotherms and thermodynamics. Chem. Int. 2, 89, 2016.

44. BABARINDE A., ONYIAOCHA G.O. Equilibrium sorption of divalent metal ions onto groundnut (Arachis hypogaea) shell: kinetics, isotherm and thermodynamics. Chem. Int. 2, 37, 2016.

45. IQBAL M., KHERA R.A. Adsorption of copper and lead in single and binary metal system onto Fumaria indica biomass. Chem. Int. 1, 157b, 2015.

46. JAFARINEJAD S. Control and treatment of sulfur compounds specially sulfur oxides (SOx) emissions from the petroleum industry: a review. Chem. Int. 2, 242, 2016.

47. JAMAL M.A., MUNEER M., IQBAL M. Photo-degradation of monoazo dye blue 13 using advanced oxidation process. Chem. Int. 1, 12, 2015.

48. MAJOLAGBE A.O., ADEYI A.A., OSIBANJO O. Vulnerability assessment of groundwater pollution in the vicinity of an active dumpsite (Olusosun), Lagos, Nigeria. Chem. Int. 2, 232, 2016.

49. NGOBIRI N., OKOROSAYE-ORUBITE K. Adsorption and corrosion inhibition characteristics of two medicinal molecules. Chem. Int. 3, 185, 2017.

50. PERVAIZ M., BUTT K.M., RAZA M.A., RASHEED A., AHMAD S., ADNAN A. Extraction and applications of aluminum hydroxide from bauxite for commercial consumption. Chem. Int. 1, 99, 2015.

51. PETER U.C., CHINEDU U. Model prediction for constant area, variable pressure drop in orifice plate characteristics in flow system. Chem. Int. 2, 80, 2016.

52. QURESHI K., AHMAD M., BHATTI I., IQBAL M., KHAN A. Cytotoxicity reduction of wastewater treated by advanced oxidation process. Chem. Int. 1, 53, 2015.

53. SHINDY H. Basics in colors, dyes and pigments chemistry: A review. Chem. Int. 2, 29, 2016.

54. UKPAKA C. Development of model for bioremediation of crude oil using moringa extract. Chem. Int. 2, 9, 2016.

55. UKPAKA C. Predictive model on the effect of restrictor on transfer function parameters on pneumatic control system. Chem. Int. 2, 128, 2016.

56. UKPAKA C. Empirical model approach for the evaluation of $\mathrm{pH}$ and conductivity on pollutant diffusion in soil environment. Chem. Int. 2, 267, 2016.

57. UKPAKA C. BTX Degradation: The concept of microbial integration. Chem. Int. 3, 8, 2016.

58. GHANEM K.M., AL-GARNI S.M., AL-ZAHRANI MA. Bioremediation of diesel fuel by fungal consortium using statistical experimental designs. Pol. J. Environ. Stud. 25, 97, 2016. 
59. HAI T., WEN-CHENG P., CHANG-FENG C., JIAN-PING X., WEN-JUN H. Remediation of acid mine drainage based on a novel coupled membrane-free microbial fuel cell with permeable reactive barrier system. Pol. J. Environ. Stud. 25, 107, 2016.

60. KWAŚNY J., BALCERZAK W. Sorbents used for biogas desulfurization in the adsorption process. Pol. J. Environ. Stud. 25, 37, 2016

61. NIE F., ZHOU Y., LIU R., LIU Z., HUANG D. Pollutant removal and PCR-DGGE analysis of microbial community structural changes in an integrated vertical-flow constructed wetland. Pol. J. Environ. Stud. 25, 709, 2016.

62. PALIULIS D. Removal of formaldehyde from synthetic wastewater using natural and modified zeolites. Pol. J. Environ. Stud. 25, 251, 2016.

63. TANEE T., SUDMOON R., THAMSENANUPAP P., CHAVEERACH A. Effect of Cadmium on DNA Changes in Ipomoea aquatica Forssk. Pol. J. Environ. Stud. 25, 311, 2016.

64. TIAN F., LIU Y., LIU C., GU H., LIU H. Pollution status and multimedia fate simulation of phthalate acid esters (PAEs) in an arid city. Pol. J. Environ. Stud. 25, 325, 2016.
65. ARADARAJAN R., VENKATESAN G., SWAMINATHAN G. Removal of copper using clay admixed with quarry fines as landfill liners. Pol. J. Environ. Stud. 25, 377, 2016.

66. ADEEL S., USMAN M., HAIDER W., SAEED M., MUNEER M., ALI M. Dyeing of gamma irradiated cotton using Direct Yellow 12 and Direct Yellow 27: improvement in colour strength and fastness properties. Cellulose. 22, 2095, 2015.

67. BOUATAY F., MEKSI N., ADEEL S., SALAH F., MHENNI F. Dyeing Behavior of the Cellulosic and Jute Fibers with Cationic Dyes: Process Development and Optimization Using Statistical Analysis. J. Nat. Fiber. 13, 423, 2016.

68. MUNEER M., ADEEL S., AYUB S., ZUBER M., URREHMAN F., KANJAL M. Dyeing behaviour of microwave assisted surface modified polyester fabric using disperse orange 25: improvement in colour strength and fastness properties. Oxid. Comm. 39, 1430, 2016. 